\title{
Efektivitas Teknik Forward Chaining Pada Kemampuan Menggunakan Kemeja Pada Anak Dengan Disabilitas Intelektual
}

\section{The Effectiveness of Forward Chaining Technique Toward The Ability of Wearing Shirt for Child with Intellectual Disability}

\author{
Jaslinder, Rini Hildayani \\ Fakultas Psikologi, Universitas Indonesia, Depok, Indonesia \\ Email: juslind.kaur@gmail.com
}

\begin{abstract}
KATA KUNCI forward chaining, disabilitas intelektual, self-dressing behavior, prompt, penguatan positif.

KEYWORDS forward chaining, intellectual disability, self-dressing behavior, prompt, positive reinforcement.
\end{abstract}

ABSTRAK Penelitian ini dilatarbelakangi adanya keterbatasan pada anak dengan disabilitas intelektual tingkat sedang yang belum mampu memakai kemeja secara mandiri. Pada sisi lain, kemeja merupakan salah satu pakaian wajib yang harus anak pakai setiap hari, terutama saat ke sekolah. Penelitian ini menggunakan program modifikasi perilaku dengan teknik forward chaining yang tujuannya mengajarkan anak untuk dapat memakai kemeja secara mandiri. Manfaat dari penelitian ini adalah membantu anak agar lebih mandiri dalam berpakaian dan dapat berfungsi dengan lebih optimal. Desain penelitian yang digunakan dalam penelitian ini adalah single subject design dengan desain penelitian A-B. Partisipan dalam penelitian ini adalah seorang anak laki-laki berusia 6 tahun 5 bulan dengan diagnosis disabilitas intelektual tingkat sedang. Program modifikasi perilaku dalam penelitian ini menggabungkan teknik forward chaining dengan beberapa teknik lainnya, seperti prompt dan positive reinforcement. Program ini terdiri dari 7 tahapan, dengan masing-masing tiga kali percobaan pada setiap tahapannya. Analisis keberhasilan efektivitas program menggunakan analisis visual dengan membandingkan data yang diperoleh ketika baseline, intervensi, dan follow up. Hasil dari penelitian ini menunjukkan bahwa penerapan teknik forward chaining bersamaan dengan prompt dan positive reinforcement terbukti efektif dalam membantu anak menguasai kemampuan untuk memakai kemeja secara mandiri. 
ABSTRACT This research is motivated by the limitations of a child with moderate intellectual disability who has not been able to dress, wear shirt independently. On the other hand, shirt is one of the daily clothes that children must wear, especially when they go to school. This research is a behavior modification program with forward chaining technique whose purpose is to teach children to be able to wear shirts independently. The benefits of this research are to help children to be more independent in dressing and to function more optimally. The research design used in this study is single subject design with an $A-B$ research design. Participant of this study is a boy aged 6 years and 5 months with a diagnosis of moderate intellectual disability. Behavior modification program in this study combines forward chaining techniques with several other techniques, such as prompt and positive reinforcement. This behavior modification program in this study consists of 7 stages, each stage consists of three trials. Analysis of the effectiveness of this program using visual analysis by comparing data obtained from baseline, intervention, and follow-up. The results of this study indicate that the application of forward chaining techniques along with prompt and positive reinforcement has proven effective in helping children master the ability to wear shirts independently.

\section{PENDAHULUAN}

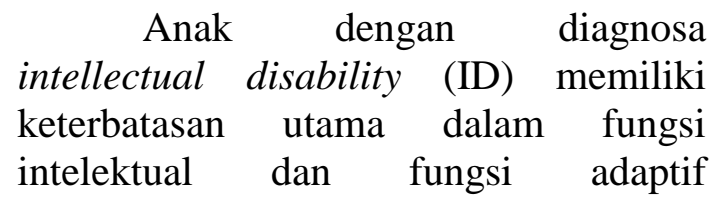
(konseptual, sosial, dan praktikal) (APA, 2013). Fungsi intelektual yang terbatas dapat ditentukan melalui tes intelegensi yang menunjukkan pada kemampuan yang berhubungan dengan kinerja akademis (Mangunsong, 2014). Sementara itu kemampuan adaptif merujuk pada kemampuan konseptual, sosial, dan praktikal yang dipelajari seseorang untuk dapat berfungsi dalam kehidupannya sehari-hari.

$\begin{array}{ll}\text { Pada anak dan remaja dengan } \\ \text { diagnosa } & \text { disabilitas intelektual, }\end{array}$ penguasaan keterampilan bina diri merupakan kemampuan penting yang harus dikuasai anak. Berkaitan dengan hal tersebut peneliti menemukan adanya keterbatasan pada anak dengan diagnosa ID level sedang usia enam tahun lima bulan yang belum mampu untuk memakai kemeja secara mandiri. Oleh karena itu tujuan dari intervensi yang peneliti berikan ini adalah melatih anak untuk dapat memakai kemeja secara mandiri.

Keterampilan memakai kemeja secara mandiri penting untuk diajarkan karena hal itu merupakan bentuk sederhana dari kemandirian anak dalam berpakaian. Menurut APA (2013), kemampuan untuk berpakaian pada anak dengan ID level sedang dapat dikembangkan walaupun membutuhkan waktu yang lebih lama dari anak dengan perkembangan tipikal dan terkadang masih memerlukan pengingat serta dukungan orang lain untuk dapat mendukungnya. 
Kemampuan yang perlu diasah atau yang bisa dilatih pada anak dengan ID level sedang, yaitu (1) belajar mengurus diri sendiri, misalnya makan, berpakaian, mandi, buang air kecil (BAK) dan buang air besar (BAB), serta tidur; (2) belajar menyesuaikan diri di lingkungan sosial, rumah atau sekitarnya; (3) mempelajari kegunaan fungsi ekonomi sederhana di rumah atau di lembaga khusus (Efendi, 2009). Oleh sebab itu, pendidikan pada anak ID level sedang cenderung ditekankan pada keterampilan mengurus diri sendiri atau bina diri dalam kehidupan sehari-hari.

Program akan dilakukan menggunakan teknik forward chaining. Forward chaining merupakan teknik mengajarkan suatu rangkaian perilaku secara bertahap satu demi satu dimulai dari langkah awal hingga akhir secara berurutan (Kazdin, 2013). Teknik ini sesuai dengan tahapan memakai kemeja yang berurutan satu demi satu, dimulai dari tahap yang paling mudah hingga yang paling sulit. Teknik berurutan dimulai dari yang paling mudah ini diharapkan dapat lebih memotivasi anak untuk belajar memakai kemeja.

Lebih lanjut, Weber

mengatakan bahwa pada dasarnya teknik chaining merupakan teknik yang efektif dalam mengajarkan anak dengan disabilitas intelektual. Secara umum, teknik chaining merupakan salah satu bentuk dari behavior modification yang melibatkan stimulus dan respon yang bertahap secara sistematis. Pada teknik ini respon terakhir juga diikuti oleh pemberian reinforcement sebagai penguat. Selain itu teknik chaining juga digunakan karena perilaku memakai baju cukup kompleks, sehingga diperlukan pemecahan langkah untuk menyelesaikan tugas memakai baju (Turner dkk, 2001).

Menurut Tekin-İftar dan Kırcaali-İftar (dalam Aykut, Emecen, Dayi, \& Karasu, 2014), behavioral chaining menjadi teknik yang dapat digunakan untuk membentuk keterampilan yang terdiri atas urutan tahapan-tahapan yang kesatuannya menjadi keterampilan yang cukup kompleks untuk dipelajari. Salah satu keterampilan tersebut adalah keterampilan merawat diri seperti makan, BAK dan BAB, serta berpakaian. Adapun riset sebelumnya yang dilakukan oleh Natasya dkk (2018) yang menunjukkan bahwa teknik forward chaining efektif meningkatkan kemampuan memakai baju pada anak dengan disabilitas intelektual level sedang.

\section{METODE PENELITIAN Partisipan}

Penelitian dilakukan terhadap L, seorang anak laki-laki berusia 6 tahun 5 bulan. L mendapatkan diagnosis disabilitas intelektual dengan tingkat keparahan sedang (moderate). Menurut keluarga hingga saat ini $\mathrm{L}$ masih mengalami kesulitan untuk memakai kemeja secara mandiri. Keluarga sempat beberapa kali memberikan L kesempatan untuk mengenakan kemejanya secara mandiri. Meski demikian, L kurang dapat memahami instruksi yang diberikan dan merasa frustrasi karena ia merasa kesulitan dan tidak mampu untuk mengancingkan kemejanya. Oleh karena itu seringkali pihak keluarga pada akhirnya membantu memakaikan kemeja L secara langsung.

\section{Desain penelitian}

Desain penelitian yang digunakan dalam penelitian ini adalah single subject design. Single subject design umumnya digunakan untuk mengukur perubahan perilaku spesifik seseorang yang merupakan hasil dari intervensi yang diberikan (Bordens \& Abbott, 2011). Pada desain penelitian subjek tunggal, pengukuran dilakukan dengan periode waktu tertentu, misalnya per minggu, per hari, atau per jam, perbandingan tidak dilakukan antarindividu, melainkan dibandingkan pada subjek yang sama dalam kondisi yang 
berbeda (Sunanto, Takeuchi, \& Nakata, 2005).

Pada penelitian ini, peneliti hanya mengukur perilaku memakai kemeja satu anak, pengukuran dilakukan pada periode waktu dua minggu. Teknik pengambilan sampel menggunakan teknik purposive sampling. Teknik purposive sampling dilakukan dengan cara mengambil subjek bukan didasarkan atas adanya strata, random tetapi didasarkan atas adanya tujuan tertentu (Poerwandari, 1998).

Dalam penelitian ini peneliti menggunakan desain penelitian A-B. Pengukuran model A-B, diawali dengan pengukuran perilaku pada tahap A (pretest), yang merupakan kondisi perilaku spesifik individu sebelum diberikan intervensi khusus atau biasa disebut baseline, dan fase B (post-test), yang merupakan fase pengukuran perilaku yang dilakukan setelah intervensi diberikan. Evaluasi dan efektivitas intervensi nantinya dapat dilihat dengan mengukur perubahan yang terjadi pada fase A dan B (Gravetter \& Forzano, 2009). Intervensi dikatakan efektif apabila anak berhasil melakukan tahapan memakai kemeja sebanyak 2 kali berturutturut dari total 3 kali percobaan yang diberikan untuk memakai kemeja secara mandiri.

\section{Setting dan peralatan penelitian}

Intervensi program dilakukan di rumah anak. Ruangan yang digunakan untuk intervensi ini adalah ruang tamu. Peralatan yang digunakan dalam intervensi ini adalah kemeja anak sendiri yang biasa digunakan untuk sekolah atau belajar mengaji dan meja.

\section{Prosedur Penelitian}

Functional Behavioral Assessment (FBA)

Setelah peneliti mendapatkan gambaran perilaku L, peneliti mengidentifikasi hubungan antara antecedent, behavior, dan consequences yang kemudian digunakan untuk merancang program modifikasi perilaku yang efektif. Identifikasi yang dilakukan peneliti disebut dengan analisis fungsi perilaku atau functional behavioral assessment (Kazdin, 2013).

Berikut ini merupakan gambaran analisis fungsi perilaku memakai kemeja pada L. Berikut merupakan tabel antecedent, behavior, dan consequence (ABC) dalam penelitian ini :

Tabel 1

Antecedents, Behavior, dan Consequence Kasus L

\begin{tabular}{|c|c|c|}
\hline Antecedents & Behavio & Consequence \\
\hline $\begin{array}{l}\text { - L belum } \\
\text { pernah } \\
\text { diajarkan } \\
\text { memakai } \\
\text { kemeja } \\
\text { secara } \\
\text { mandiri oleh } \\
\text { kakek, } \\
\text { nenek, dan } \\
\text { tante. } \\
\text { - L selalu } \\
\text { dibantu oleh } \\
\text { kakek, } \\
\text { nenek, dan } \\
\text { tante untuk } \\
\text { memakai } \\
\text { kemeja. } \\
\text { - Kakek, } \\
\text { nenek, dan } \\
\text { tante tidak } \\
\text { tahu cara } \\
\text { mengajari L } \\
\text { mengancing } \\
\text { kan kemeja. }\end{array}$ & \begin{tabular}{l}
\multicolumn{1}{c}{$\boldsymbol{r}$} \\
Belum \\
adanya \\
perilak \\
u \\
memak \\
ai \\
kemeja \\
yang \\
dilakuk \\
an \\
secara \\
mandir \\
i
\end{tabular} & $\begin{array}{l}\text { Kakek, } \\
\text { nenek, } \\
\text { dan } \\
\text { tante } \\
\text { harus } \\
\text { selalu } \\
\text { memba } \\
\text { ntu L } \\
\text { untuk } \\
\text { memak } \\
\text { aikan } \\
\text { kemeja }\end{array}$ \\
\hline
\end{tabular}

\section{Rancangan Program Intervensi}

Program modifikasi perilaku ini bertujuan untuk mengajarkan kemampuan memakai kemeja yang meliputi tujuh tahap. Tiap sesi berlangsung selama 30-60 menit yang dilakukan setelah anak pulang sekolah. Program modifikasi perilaku dalam penelitian ini menggunakan teknik forward chaining dilengkapi dengan pemberian positive reinforcement dan 
prompting fisik dan verbal untuk membantu mengajarkan L memakai baju kemeja.

Dalam melatih kemandirian anak dengan berkebutuhan khusus kerapkali perilaku yang menjadi target harus dijabarkan ke dalam beberapa tahapan kecil. Hal pertama yang dilakukan untuk melatih kemampuan bina diri anak dengan kebutuhan khusus adalah dengan membuat task analysis (Kazdin, 2013). Task Analysis merupakan pembagian perilaku spesifik yang menjadi target modifikasi perilaku ke dalam tahap-tahap kecil (Martin \& Pear 2010). Task analysis dibuat oleh peneliti dengan sesederhana mungkin berdasarkan tahapan berpakaian atau dressing skills. Selain itu, dalam pembuatan task analysis, peneliti juga harus mencobakannya sendiri untuk memastikan apakah task analysis yang dirancang sudah sesuai dengan karakteristik anak dan sudah sangat sederhana untuk diaplikasikan kepada anak nantinya.

Tahapan-tahapan yang akan dilatih dalam intervensi ini adalah

- Tahap 1: mengambil kemeja dari dalam lemari.

- Tahap 2: membentangkan kemeja di meja atau sofa.

- Tahap 3: membuka kancing satu per satu.

- Tahap 4: mengangkat kemeja dan menghadapkan bagian kemeja yang terbuka ke hadapan anak.

- Tahap 5: memasukkan tangan kanan ke lubang kemeja bagian kiri.

- Tahap 6: memasukkan tangan kiri ke lubang kemeja satunya.

- Tahap 7: mengancingkan kemeja.

Berikut ini adalah behavioral chaining untuk perilaku memakai kemeja berdasarkan hasil task analysis:

- $\quad\left(\mathrm{S}^{\mathrm{D}}\right)$ kemeja di dalam lemari $\rightarrow\left(\mathrm{R}_{1}\right)$ mengambil kemeja di lemari.

- $\left(\mathrm{S}_{2}{ }_{2}\right)$ kemeja di tangan $\rightarrow\left(\mathrm{R}_{2}\right)$ meletakkan kemeja di meja.

- $\left(\mathrm{S}_{3}{ }_{3}\right)$ kemeja di meja $\rightarrow\left(\mathrm{R}_{3}\right)$ membuka kancing kemeja satu per satu.
- $\left(\mathrm{S}_{4}{ }_{4}\right)$ kancing terbuka $\rightarrow\left(\mathrm{R}_{4}\right)$ anak mengangkat kemeja bagian terbuka menghadap ke anak.

- $\left(\mathrm{S}_{5}^{\mathrm{D}}\right)$ kemeja diangkat bagian terbuka menghadap ke anak $\rightarrow\left(\mathrm{R}_{5}\right)$ anak memasukkan tangan kanan ke lengan kemeja bagian kiri.

- $\left(\mathrm{S}_{6}^{\mathrm{D}}\right)$ tangan kanan ada di lengan kemeja kanan $\rightarrow\left(\mathrm{R}_{6}\right)$ tangan kiri menggapai lengan kemeja satunya.

- $\quad \mathrm{S}^{\mathrm{D}}{ }_{7}$ Badan sudah memakai kemeja dengan terbuka $\rightarrow \quad\left(\mathrm{R}_{7}\right)$ mengancingkan kemeja satu per satu hingga terkancing semuanya.

Program modifikasi perilaku ini disusun ke dalam tujuh sesi dan terdiri dari tujuh tahapan memakai kemeja. Dalam setiap sesi, anak akan dilatih seluruh tahapan memakai kemeja. Akan tetapi, terdapat beberapa tahap yang menjadi target penguasaan di setiap sesi. Contohnya, sesi satu memiliki dua target (tahap satu dan dua) tahapan perilaku memakai kemeja yang harus dikuasai anak.

Tabel 2

Tahapan Sesi

\begin{tabular}{ll}
\hline $\begin{array}{c}\text { Tahapan Sesi } \\
\text { Pelaksanaan }\end{array}$ & \multicolumn{1}{c}{$\begin{array}{c}\text { Target } \\
\text { Penguasaan } \\
\text { Perilaku }\end{array}$} \\
\hline Sesi 1 & Tahap 1,2 \\
Sesi 2 & Tahap 1,2,3 \\
Sesi 3 & Tahap 1,2,3,4 \\
Sesi 4 & Tahap 1,2,3,4,5,6 \\
Sesi 5 & Tahap \\
Sesi 6 & 1,2,3,4,5,6,7 \\
& Tahap 1,2,3,4,5, \\
Sesi 7 & $\begin{array}{l}\text { Generalisasi } \\
\text { (menggunakan }\end{array}$ \\
& $\begin{array}{l}\text { kemeja yang } \\
\text { sebelumnya } \\
\text { belum pernah } \\
\text { dipakai selama } \\
\text { sesi intervensi) }\end{array}$ \\
&
\end{tabular}


Dalam setiap sesi anak memiliki kesempatan tiga kali percobaan. Secara umum pelaksana intervensi akan memberikan kedua prompting (physical prompt dan verbal prompt) pada percobaan pertama atau pada percobaan kedua serta ketiga saat anak merasa kesulitan dan mulai menunjukkan distress. Anak dikatakan berhasil pada satu sesi, jika ia mampu menunjukkan tahapan perilaku memakai kemeja sesuai dengan target setiap sesi sebanyak dua kali secara berurutan tanpa physical prompt dari total tiga kali percobaan yang diberikan.

Percobaan pada setiap langkah dianggap gagal apabila setelah lebih dari 10 menit perilaku yang diharapkan belum dimunculkan. Saat anak gagal mencapai target pada satu sesi, maka sesi tersebut harus diulang kembali hingga anak berhasil dan maju ke sesi selanjutnya.

Tabel 3

Observasi Pelaksanaan

\begin{tabular}{|c|c|c|c|}
\hline Tahapan & Sesi 1 & Sesi 2 & $\begin{array}{c}\text { Sesi } 3 \\
\text { dst.. }\end{array}$ \\
\hline & $\begin{array}{lll}12 & 3\end{array}$ & 123 & $\begin{array}{lll}1 & 2 & 3\end{array}$ \\
\hline $\begin{array}{l}\text { 1. Mengambi } \\
\text { l kemeja } \\
\text { dari dalam } \\
\text { lemari }\end{array}$ & $x \quad \sqrt{ }$ & & \\
\hline $\begin{array}{l}\text { 2. Membenta } \\
\text { ngkan } \\
\text { kemeja di } \\
\text { meja atau } \\
\text { sofa }\end{array}$ & & $\sqrt{ } \sqrt{ } \sqrt{ }$ & \\
\hline $\begin{array}{l}\text { 3. Membuka } \\
\text { kancing } \\
\text { satu per } \\
\text { satu }\end{array}$ & & & $\sqrt{ } \sqrt{ }$ \\
\hline $\begin{array}{l}\text { 4. Mengangk } \\
\text { at kemeja } \\
\text { dan } \\
\text { menghada } \\
\text { pkan } \\
\text { bagian } \\
\text { kemeja } \\
\text { yang } \\
\text { terbuka ke }\end{array}$ & & & \\
\hline
\end{tabular}

hadapan

anak

5. Memasuk

kan tangan

kanan ke

lubang

kemeja

bagian kiri

6. Memasuk

kan tangan

kiri ke

lubang

kemeja

satunya

7. Menganci

ngkan

kemeja

\section{Prompting}

Selain teknik forward chaining, dalam program modifikasi perilaku L ini ada beberapa teknik yang ikut disertakan dalam program yaitu teknik prompting dan reinforcement. Teknik prompting digunakan untuk membantu $\mathrm{L}$ dalam menguasai tahapan-tahapan dalam memakai kemeja. Prompting yang diberikan kepada L terbagi menjadi dua yaitu physical prompts dan verbal prompt. Physical prompt merupakan arahan atau bimbingan yang diberikan kepada $\mathrm{L}$ dalam bentuk fisik untuk membantu $\mathrm{L}$ menguasai tahap-tahap memakai kemeja yang sudah ditentukan. Sementara itu, verbal prompt merupakan arahan atau bimbingan yang diberikan kepada $\mathrm{L}$ dalam bentuk instruksi secara verbal.

Dalam program ini, orang yang memberikan prompting secara fisik maupun verbal adalah peneliti sendiri. Contoh prompting fisik yang diberikan yaitu mengarahkan tangan anak ke kancing baju atau ke lubang kancing. Adapun contoh instruksi verbal yang diberikan saat menjalankan program yaitu 
"Ayo ambil kemejanya di dalam lemari" dan "Ayo angkat tangan kanannya turunkan dan masukkan menyilang lengan kemeja bagian kiri”"

\section{Reinforcement}

Sistem lain yang juga digunakan dalam program ini selain forward chaining dan prompting adalah diterapkannya sistem reinforcement. Reinforcement atau penguatan adalah proses di mana perilaku diperkuat oleh konsekuensi langsung yang reliabel mengikuti kejadiannya. Bila perilaku diperkuat, kemungkinan perilaku akan terjadi atau muncul kembali di masa depan (Kazdin,2013).

Dalam penelitian ini peneliti mencari tahu hal apa yang disukai anak dengan meminta tante mengisi lembar reinforcement saat tahap baseline. Berdasarkan lembar reinforcement tersebut peneliti kembali berdiskusi mengenai pemilihan reinforcement yang sebaiknya diberikan pada saat program dijalankan. Peneliti juga melakukan pengecekan kepada L secara langsung dengan bertanya mengenai hal-hal apa saja yang L sukai dan inginkan.

Penyusunan daftar reinforcement diberikan berdasarkan kesukaan serta kemudahan akses nenek dan tante untuk mendapatkannya. Semakin tinggi target yang dicapai maka semakin berharga reinforcement tersebut untuk anak. Berdasarkan data baseline reinforcer yang dipilih adalah social reinforcers dan consumable reinforce. Contoh dari social reinforcer adalah memberikan pujian, tepukan tangan, ajakan tos, dan acungan jempol.

Pemberian reinforcer diberikan setiap L berhasil melakukan tahapan memakai kemeja. Consumable reinforcer diberikan di akhir saat anak berhasil menyelesaikan suatu sesi sesuai target yang sudah ditentukan. Contoh consumable reinforcer yang disukai anak yaitu biskuit coklat, es krim, dan keripik.

\section{Baseline}

Pengambilan baseline dilakukan di rumah anak sepulang sekolah. Pelaksanaan baseline dilakukan selama tiga hari berturut-turut. Pada saat baseline, peneliti meminta anak untuk mangambil kemejanya dan memakainya sendiri tanpa bantuan dari orang sekitar, baik secara verbal maupun fisik. Berdasarkan tahapan task analysis memakai kemeja yang sudah ditentukan, saat baseline, anak belum menunjukkan satu pun kemampuannya dalam tahapan memakai kemeja yang secara konsisten tepat.

\section{Intervensi}

Pada awalnya intervensi diberikan di dalam tujuh sesi dalam dua minggu. Jumlah sesi ditambahkan satu sesi dari penentuan awal yang hanya tujuh sesi. Hal itu karena anak sempat gagal pada sesi keenam sehingga keesokan harinya peneliti melakukan kembali sesi tersebut sehingga total menjadi delapan sesi. Sesi intervensi dilaksanakan sekitar pukul 13.00-14.00.

\section{Follow up}

Follow up dilakukan sebanyak dua kali yang pertama dilakukan 3 hari setelah intervensi selesai diberikan dan dua minggu setelah follow up pertama. Hasil kedua follow up menunjukkan bahwa perubahan perilaku memakai kemeja L tetap bertahan secara positif. 
ANALISIS \& HASIL

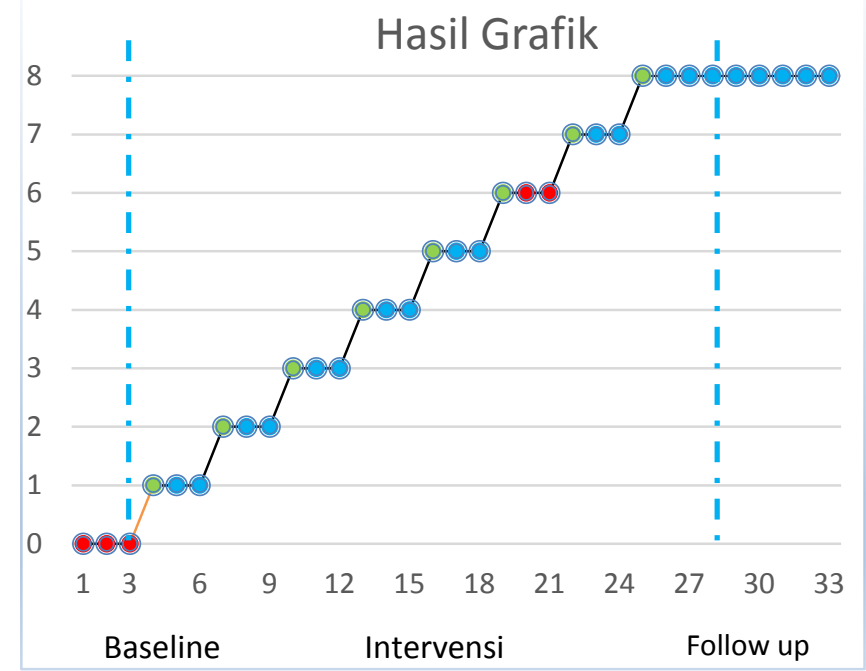

Gambar 1. Kemampuan anak memakai kemeja pada tahap baseline, intervensi, dan follow up

\section{Keterangan :}

- Warna merah menandakan anak gagal

- Warna hijau menandakan anak berhasil dengan bantuan

- Warna biru menandakan anak berhasil dengan mandiri

Gambar satu menunjukkan bahwa terdapat peningkatan kemampuan memakai kemeja yang dilakukan oleh anak. Secara umum, kemampuan penguasaan rangkaian perilaku memakai kemeja pada anak menunjukan adanya peningkatan, dilihat dari percobaan satu hingga percobaan ke 27. Perbandingan hasil baseline dan follow up juga menunjukkan bahwa anak yang pada awalnya belum menguasai langkahlangkah memakai kemeja dengan benar pada akhirnya dapat menguasai keseluruhan rangkaian perilaku memakai kemeja dengan benar dimulai dari mengambil kemeja dari dalam lemari, membentangkan kemeja di meja atau sofa, membuka kancing satu per satu, mengangkat kemeja dan menghadapkan bagian kemeja yang terbuka ke hadapan anak, memasukkan tangan kanan ke lubang kemeja bagian kiri, memasukkan tangan kiri ke lubang kemeja satunya, hingga yang terakhir mengancingkan kemeja.

Selain itu, hasil grafik juga menunjukkan bahwa kemampuan anak tetap bertahan bahkan pada sesi follow up satu dan saat response maintenance (follow up dua). Dengan begitu dapat dikatakan bahwa kemampuan memakai kemeja pada anak secara konsisten sudah dikuasainya.

Hasil intervensi ini juga menunjukkan bahwa saat ini pada dasarnya anak sudah memahami konsep rangkaian memakai kemeja dengan tepat dan jika suatu saat anak mengalami kesulitan untuk mengancingkan orang tua dapat memberikan prompting secara verbal terlebih dahulu dan prompting fisik jika diperlukan namun tidak lagi untuk dipakaikan atau dibantu sepenuhnya

Hasil kualitatif lain yang didapatkan dari program ini adalah saat ini L lebih dapat menujukkan perilaku yang lebih tenang. Saat menghadapi kesulitan, L tidak lagi menunjukkan emosi negatif atau frustrasi pada diri sendiri dan orang lain, melainkan mencoba dengan lebih tenang, tidak marah, merengek, atau menangis.

Dalam hal reinforcer, ada perbedaan yang terjadi pada rancangan dan pelaksanaan intervensi. Pada awalnya, peneliti sudah mengurutkan reinforcer yang sesuai dengan beban dari target yang ingin dicapai di setiap sesinya. Hanya saja pengasuh tidak menyediakan reinforcer yang sesuai, misalnya seharusnya L mendapatkan reinforcer keripik pada sesi satu, namun pengasuh menyediakan biskuit. Meskipun demikian hal tersebut tidak terlihat berdampak besar karena pada dasarnya anak menyukai makanan ringan jenis apapun. Penggunaan bentuk consumable reinforcer pada program ini terbukti dapat meningkatkan dan mempertahankan perilaku memakai kemeja pada anak

\section{DISKUSI}

Berdasarkan hasil penelitian, teknik forward chaining bersamaan 
dengan prompt dan positive reinforcement terbukti efektif dalam meningkatkan perilaku berpakaian (memakai kemeja). Jika dibandingkan dengan data baseline kondisi saat anak belum mampu melakukan tahapan memakai baju dengan benar, hingga saat follow up anak sudah mampu melakukan tahapan memakai baju secara mandiri dengan benar dimulai dari tahap awal mengambil baju hingga pada akhirnya mampu mengancingkannya secara mandiri.

Adapun hal lain yang juga turut membantu keberhasilan program adalah dukungan dan kerja sama dari pihak keluarga untuk turut serta menjalankan program dan memberikan reinforcement secara konsisten kepada anak, contohnya consumable reinforcer baru diberikan ketika L berhasil menguasai suatu sesi. Selama program L juga kerap melakukan private speech. Menurut Vygotsky, private speech dapat digunakan anak sebagai cara untuk menyelesaikan suatu masalah (dalam Wade \& Tavris, 2008). L menggunakan suara atau perkataan yang ditujukan pada dirinya sendiri. Selain itu, sikap L yang juga cenderung dapat diarahkan, bersemangat, dan tidak mudah putus asa membuat dirinya termotivasi dan mau menjalankan program sesuai dengan arahan peneliti.

Meskipun demikian masih terdapat keterbatasan dalam program ini, yang pertama adalah tidak ditetapkannya waktu jeda atau istirahat yang jelas antar percobaan kesatu, dua dan ketiga. Oleh karena itu anak cenderung merasa bosan, tidak fokus dan menunjukkan sikap yang negatif seperti merengek, atau berlari menghindari aktivitas. Menurut Tomporowski dan Tinsley (dalam Hallahan \& Kauffman, 2006), anak yang mengalami intellectual disability memiliki masalah dalam memusatkan perhatiannya, cenderung sulit fokus, mudah bosan dan sulit mempertahankan perhatiannya terhadap materi yang sedang diajarkan.

Faktor kedua yang juga menjadi keterbatasan dalam penelitian ini yaitu tidak adanya kesepakatan dengan orang tua maupun anak dalam penentuan kemeja yang digunakan selama program berlangsung. Hal itu dapat berdampak pada keberhasilan program misalnya saja dalam penelitian ini, anak cenderung kesulitan saat kemeja yang disediakan sudah berukuran terlalu sempit, serta anak perlu menyesuaikan diri kembali saat kemejanya berganti dari lengan panjang ke lengan pendek dan sebagainya.

\section{SIMPULAN}

Berdasarkan paparan di atas, dapat disimpulkan bahwa program modifikasi perilaku dengan teknik forward chaining bersamaan dengan prompting dan positive reinforcement terbukti efektif dalam meningkatkan perilaku memakai kemeja pada anak dengan disabilitas intelektual tingkat sedang.

\section{SARAN}

Program sebaiknya melibatkan beberapa aktivitas bermain yang menyenangkan untuk anak. Hal itu dilakukan untuk menarik perhatian anak saat anak mulai terdistrak dari lingkungan sekitar yang mungkin lebih menyenangkan. Aktivitas bermain juga disiapkan agar anak lebih semangat saat menjalankan program, serta mengantisipasi rasa bosan yang mungkin muncul pada saat program dilaksanakan.

\section{DAFTAR PUSTAKA}

American Psychiatric Association (2013). Diagnostic and statistical manual of mental disorder $5^{\text {th }}$ edition. Washington, DC: Author.

Aykut, C., Emecen, D.D., Dayi, E., \& Karasu, N. (2014). Teaching chained tasks to students with intellectual disabilities by using video prompting in small group instruction. Educational Sciences: Theory \& Practice, 14(3), 10821087.

Bordens, K.S. \& Abbott, B.B. (2011). Research design and methods: A process approach $\left(8^{\text {th }} e d\right.$. $)$. New York: Mc Graw Hill. 
Efendi, M. (2009). Pengantar psikopedagogik anak berkelainan. Jakarta: Bumi Aksara.

Gravetter, F. J. \& amp; Forzano, L. B. (2009). Research methods for the behavioral science $\left(3^{\text {rd }}\right.$ ed). Canada: Cengage Learning.

Hallahan, D.P \& Kauffman, J.M. (2006). Exceptional learners: An introduction to special education. $\left(10^{\text {th }} \mathrm{ed}\right)$. Massachusetts: Allyn and Bacon.

Kazdin, A.E. (2013). Behavior modification in applied settings $\left(7^{\text {th }}\right.$ ed.). Illinois: Waveland Press.

Martin, G. \& Pear, J. (2010). Behavior modification: what it is and how to do it ( $9^{\text {th }}$ ed. examination copy). New Jersey: Pearson Prentice Hall.

Poerwandari, E. K. (1998). Pendekatan kualitatif dalam penelitian psikologi. Jakarta: LPSP3 Fakultas Psikologi Universitas Indonesia.

Sunanto, J., Takeuchi, K., \& Nakata, H. (2005). Pengantar penelitian dengan subjek tunggal. Jepang: University of Tsukuba.

Turner, L., Lammi, B., Friesen, K., \& Phelan, N. (2001). Your child dressing's workbook. Retrieved from

https://www.cshsurrey.co.uk/ourservices/servicechildren/occupational-therapy.

Wade, C. \& Tavris, C. (2008). Psychology $\quad 9^{\text {th }}$ ed. California: Pearson.

Weber, N.J., (1978). Chaining strategies for teaching sequenced motor tasks to mentaly retarded adults. The American Journal of Ocupational Therapy, 32(6), 385389. 